\title{
Cytomorphological Studies and Seed Protein Characterization of Nigella sativa L. and Nigella damascena L.
}

\author{
Animesh Kumar Datta* and Aditi Saha \\ Department of Botany, Cytogenetics and Plant Breeding Section, \\ Kalyani University, Kalyani-741235, West Bengal, India \\ Received December 19, 2002; accepted December 26, 2002
}

\begin{abstract}
Summary Cytomorphological studies including scanning electron microscopy of the seed surfaces and seed protein characterization have been performed to ascertain interrelationship between 2 species of Nigella (Ranunculaceae) namely, Nigella sativa L. (black cumin: spice of commerce) and Nigella damascena L. (love-in-a-mist: ornamental) and the results obtained have been discussed. Further, in this investigation it has also been noted that a line of $N$. damascena obtained from Royal Botanic Garden, Kew, London possessed unique ornamental phenotype and yielded good number of viable seeds per plant which were with high protein content.
\end{abstract}

Key words Nigella sativa, Nigella damascena, Cytomorphology, SEM, SDS-PAGE.

Black cumin (Nigella sativa L., $2 n=12$ ), a member of the family Ranunculaceae is widely cultivated for spice yielding property and therapeutic uses (Pruthi 1998) including anticancerous activity (Worthen et al. 1998). Improvement in N. sativa has been attempted through induced mutagenesis and colchiploidy and some desirable 'plant types' have been screened (Datta and Biswas 1985, 1986a, b, Rang and Datta 2001, Datta and Rang 2001, Datta and Saha 2001, Saha and Datta $2002 \mathrm{a}-\mathrm{c})$. However, improvement in yield and quality in $N$. sativa can also be made by exploring gene pool from related species. Nigella damascena L. (commonly known as love-in-a-mist, $2 n=12$ ) possessing unique floral characteristics and bushy habit with enhanced number of branches and capsules and with higher seed protein content (Chakraborty and Chakraborty 1964), is one such species. Transfer of the better traits from $N$. damascena to $N$. sativa is most desirable but such attempts have not been made; although, such crosses might be successful as both species have equal chromosome number. Present investigation deals with cytomorphological studies including scanning electron microscopy of seed surfaces of $N$. sativa and $N$. damascena to ascertain interrelationship between the species for species hybridization. Further, electrophoretic pattern of seed protein has also been observed to decipher the similarities and differences between the species.

\section{Materials and methods}

Seed samples of Nigella sativa L. (cultivated variety-Persian jewels) and N. damascena (cultivated variety-Miss jekyll blue) obtained from 'Sutton and Sons', Kolkata and New Delhi respectively and N. damascena (accession no. 0016287) collected from Royal Botanic Garden, Kew, London were used in the present investigation.

\section{Morphological studies}

Plants from 3 seed stocks were raised (sowing of seeds on same date-15th November) in the experimental field of Kalyani University during the year 1998-1999 and to avoid any phenotypic

\footnotetext{
* Corresponding author
} 
variations due to environment, the selfed lines of those plants were grown in 2 subsequent generations (1999-2000, 2000-2001) in randomized block design with 3 replications (2000-2001). Each plot $(4 \mathrm{~m} \times 2 \mathrm{~m})$ consisted of 4 rows with spacing of $40 \mathrm{~cm}$ between rows and $30 \mathrm{~cm}$ between plants. Twenty five ( $N$. damascena-Sutton) to 32 ( $N$. sativa and $N$. damascena-Kew) randomly selected plants from 3 replications were estimated for different qualitative and quantitative morphological attributes from seedling stage to maturity (Table 1). Flowers of identical maturity were used for colour identification and the colours were determined from Horticultural colour chart I and II (1968). Pigmentation on the suture of the fruits in $N$. damascena plant types was also identified. Seed viability of the plant types was tested by dipping half seeds ( 50 half seeds from each plant type) in $1 \%$ aqueous solution of tetrazolium chloride for $24 \mathrm{~h}$ and embryos of seed stained red were considered viable.

Seed surface study following Scanning Electron Microscopy: For SEM studies, dry and clear seeds from each plant type (mother stock in each case) were fixed on a stud with double sided tape. They were coated with gold palladium using SEM coating unit ES 100 (Polorom Equipment Ltd.) and observed under SEM test (Model-JSM 5200 Tokyo, Japan) at $25 \mathrm{kV}$ accelerating voltage at USIC, Jadavpur University, Kolkata. The photographs were taken at different magnifications.

\section{Cytological studies}

Karyotype analysis was made (seeds of original mother stock have been used) in the plant types following Datta and Biswas (1983). For meiotic studies, flower buds from the plant types (plants raised from original mother stock) of proper sizes were fixed in acetic alcohol $(1: 3)$ for $24 \mathrm{~h}$ and preserved in $70 \%$ alcohol. Anthers were squashed in $1 \%$ acetocarmine stain. Pollen fertility was assessed from temporary smears of pollen grains of freshly open flowers in drop of $1 \%$ acetocarmine. Stained pollen grains were considered fertile.

\section{Seed protein characterization}

Seed protein content of the 3 plant types (seeds of original mother stocks have been used) was estimated following Lowry et al. (1951). To study seed protein polymorphism, SDS-PAGE (10.0\% separating gel and $4.5 \%$ stacking gel) was carried out in 2 dimensional gel following Laemmli (1970) in a vertical gel system (Biotech). Protein was loaded in each lane $(30 \mu \mathrm{m})$ and the gel was stained in Coomassie Brilliant blue-R250 for overnight. Relative mobility $\left(\mathrm{R}_{\mathrm{m}}\right)$ of the protein bands was determined after destaining and fixation of the gel.

\section{Chlorophyll estimation}

Quantitative assessment of chlorophyll ' $a$ ' and chlorophyll ' $b$ ' was made from leaf tissues (of same maturity) of the plant types (plants raised from seeds of mother stocks) following the method of Arnon (1949).

\section{Estimation of essential oil}

Essential oil was quantitatively assessed from seeds of the plant types (due to paucity of seeds of original mother stocks, seeds obtained from selfed lines in 2000-2001 were used; 3 replicas in each case and $1 \mathrm{~g}$ seed was used for each set of experiment) following steam distillation process as mentioned by Sengupta (2001).

\section{Results and discussion}

\section{Morphological characteristics}

On examination of the qualitative morphological characteristics (Table 1) it can be inferred that $N$. sativa having an erect habit (Fig. 1) varied conspicuously from the plant types of N. damas- 


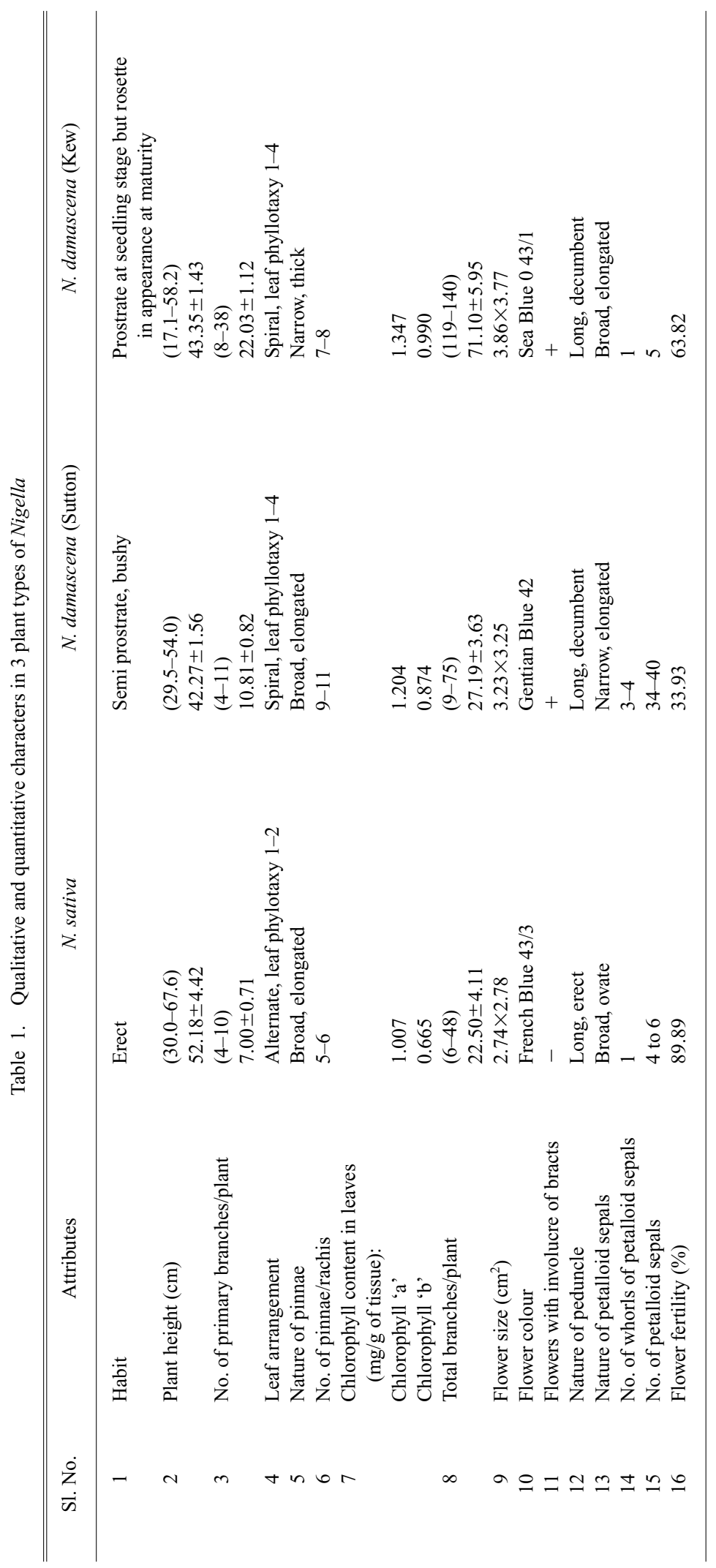




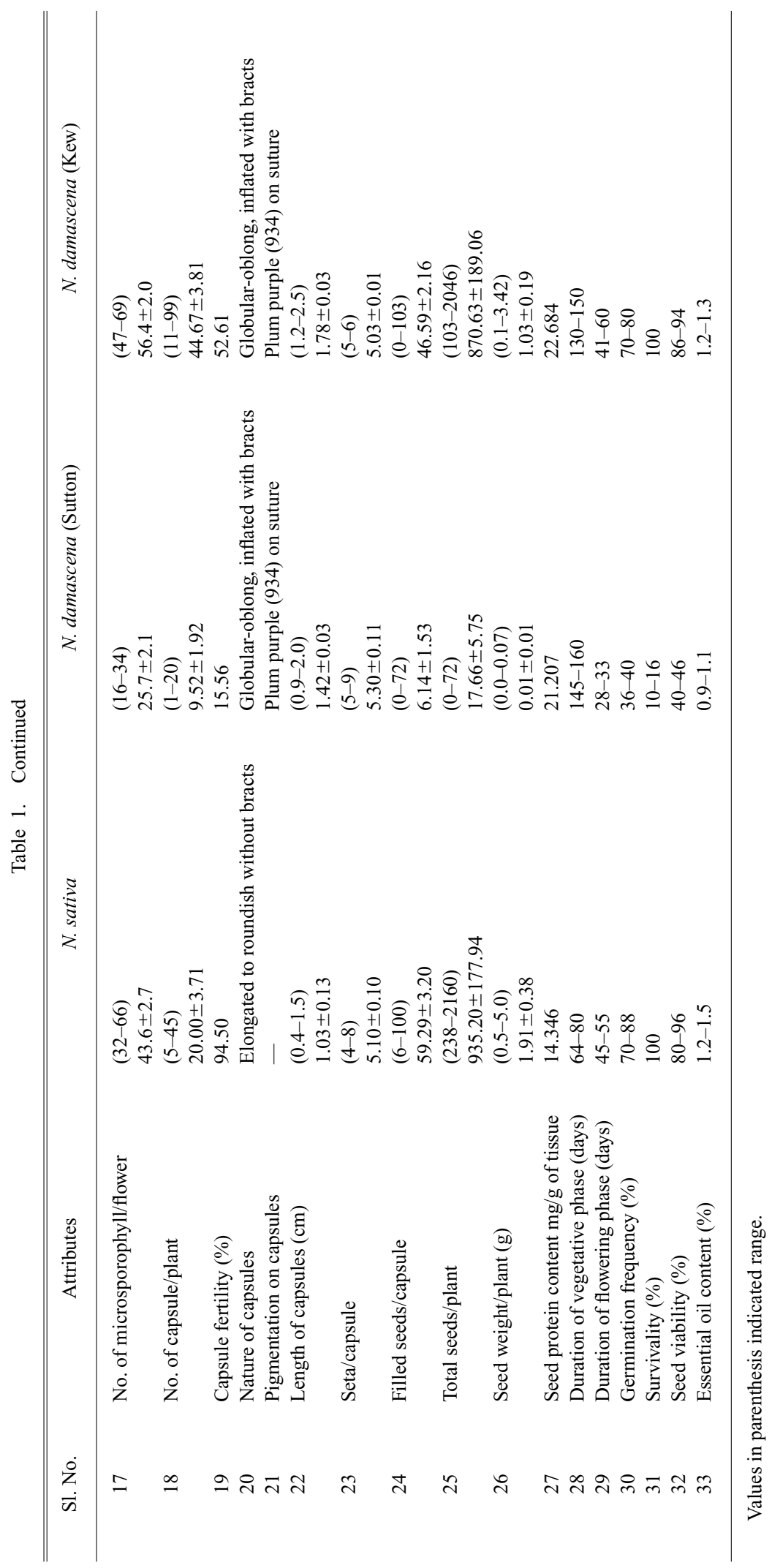



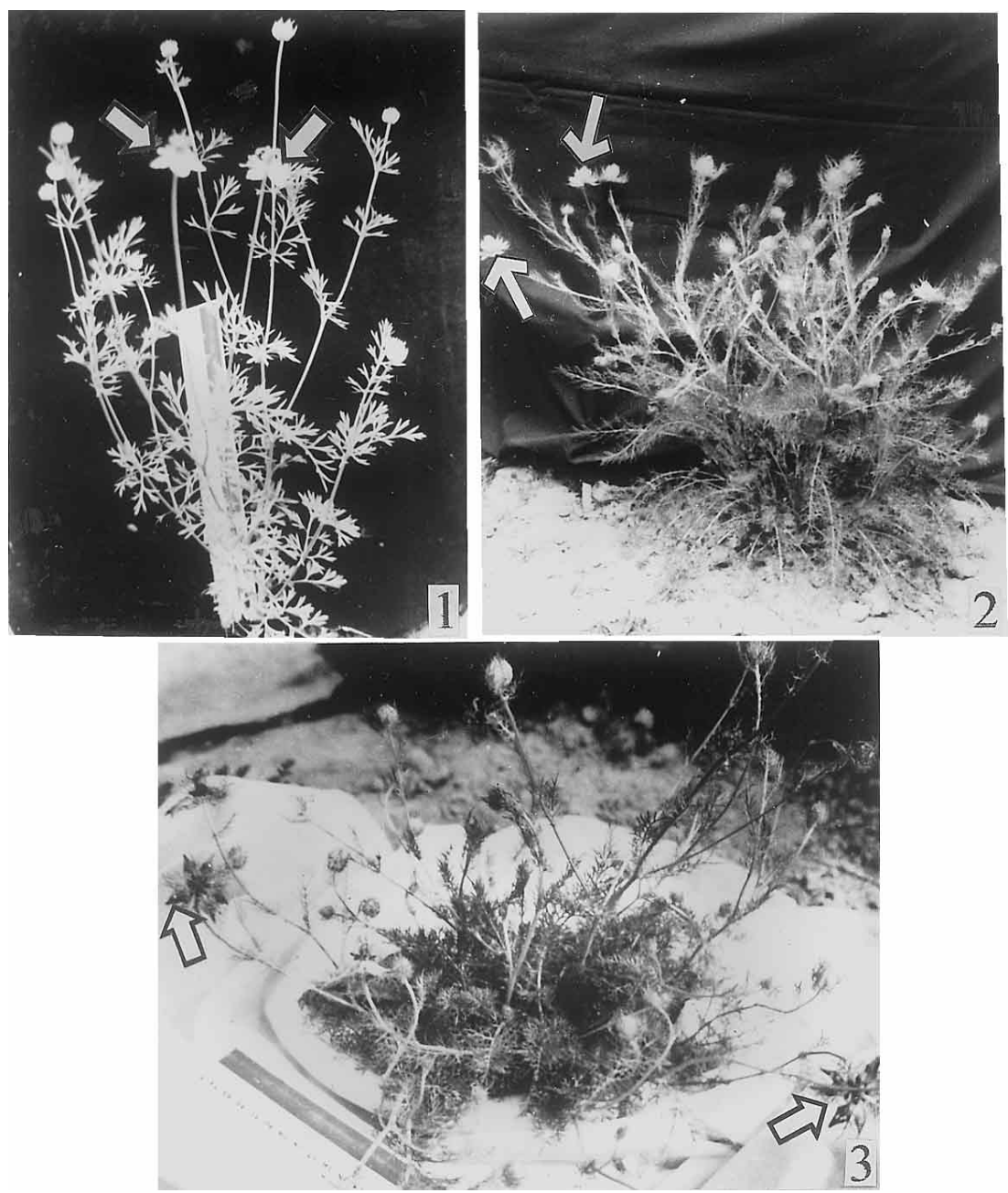

Figs. 1-3. 1) Erect habit in N. sativa. 2) Semi-bushy nature of $N$. damascena-Sutton. 3) $N$. damascena-Kew showing rosette habit with long decumbent floral shoots.

cena; while, $N$. damascena-Sutton and $N$. damascena-Kew plants differed markedly between themselves in relation to habit (Figs. 2, 3), nature of pinnae, floral characteristics, survivality and seed viability. Similarly, quantitative morphological attributes (Table 1) were found to vary significantly among the plant types $(p<0.001$ in all cases excepting capsule length which showed variation at 0.05 probability level; however, seta per capsule showed non-significant variations) and between the plant types of $N$. damascena $(p<0.001$ in all cases excepting plant height which demonstrated nonsignificant variation) as evidenced from $\chi^{2}$ test of heterogeneity and $t$-test respectively.

Having enhanced flower and capsule sterilities, the $N$. damascena-Sutton plants were mostly seedless and rarely yielded few good seeds per plant and the seeds were poor in viability (Table 1). Further, the plants of $N$. damascena-Sutton showed sign of drying up at the flowering stage (April-May). On the contrary, $N$. damascena-Kew plants produced enhanced number of flowers, capsules and seeds per plants and manifested 100\% survivality (Table 1), thereby suggesting their good adaptability in present condition. These plants possessed unique rosette phenotypes with thick dark green pinnae of leaves and large flowers and had single whorl of petalloid sepals in flowers like N. sativa (Figs. 1, 3, $\Rightarrow$ ). Persistent presence of 3 to 4 whorls of petalloid sepals in flowers of 
Table 2. SEM analysis of seed surfaces of three plant types

\begin{tabular}{|c|c|c|c|c|}
\hline S1. No. & Attributes & N. sativa & N. damascena (Sutton) & N. damascena (Kew) \\
\hline 1 & Seed shape & $\begin{array}{l}\text { Ovate, tetrangular, angles } \\
\text { sharp, acute, more tapering } \\
\text { at the end (Fig. } 4 \text { ) }\end{array}$ & $\begin{array}{l}\text { Ovate, triangular, angles } \\
\text { sharp, acute, shallow } \\
\text { tapering at the end (Fig. 8) }\end{array}$ & $\begin{array}{l}\text { Ovate, triangular, angles } \\
\text { sharp, acute, tapering at } \\
\text { one end (Fig. 12) }\end{array}$ \\
\hline 2 & Seed size $\left(\mathrm{cm}^{2}\right)$ & $2.33 \pm 0.1 \times 1.14 \pm 0.02$ & $2.30 \pm 0.1 \times 1.64 \pm 0.05$ & $1.95 \pm 0.05 \times 1.24 \pm 0.04$ \\
\hline 3 & Seed surface & $\begin{array}{l}\text { Reticulaton marks present, } \\
\text { reticulation more } \\
\text { prominently raised, } \\
\text { reticulation pentagonal to } \\
\text { polygonal, ovoid or } \\
\text { irregular in outline (Fig. 5) }\end{array}$ & $\begin{array}{l}\text { Reticulation marks present, } \\
\text { reticulation mediumly } \\
\text { raised, reticulation tetra- } \\
\text { and pentagonal, ovoid } \\
\text { (Fig. 9) }\end{array}$ & $\begin{array}{l}\text { Reticulaton marks present, } \\
\text { reticulation prominently } \\
\text { raised, reticulaton tetra-, } \\
\text { penta-, and polygonal } \\
\text { (Fig. 13) }\end{array}$ \\
\hline 3.1 & $\begin{array}{l}\text { Nature of reticulate } \\
\text { rows }\end{array}$ & $\begin{array}{l}\text { Reticulate rows (Fig. } 5- \\
\Rightarrow \text { ) consisting of smaller } \\
\text { tuberculate raised cell } \\
\text { (Fig. } 7-\Rightarrow \text { ); cells either } \\
\text { uni- or multiseriate or in } \\
\text { aggregation along the } \\
\text { corners or junctions }\end{array}$ & $\begin{array}{l}\text { Reticulate rows (Fig. 9- } \\
\Rightarrow \text { ) consisting of } \\
\text { tuberculate raised cell; cells } \\
2 \text { to } 3 \text { seriate; uniformly } \\
\text { arranged never aggregated }\end{array}$ & $\begin{array}{l}\text { Reticulate rows (Fig. 13- } \\
\Rightarrow \text { ) consisting of smaller } \\
\text { tuberculate raised cell; } \\
\text { commonly of } 4 \text { to } 5 \text { rows, } \\
\text { no aggregation along } \\
\text { junction or corner }\end{array}$ \\
\hline 3.2 & $\begin{array}{l}\text { Cells of reticulate } \\
\text { lines }\end{array}$ & $\begin{array}{l}\text { Showed shrinkage } \\
\text { structure }\end{array}$ & $\begin{array}{l}\text { Undifferentiated mass, } \\
\text { coated dermal appearance } \\
(\text { Fig. } 10-\Longrightarrow)\end{array}$ & $\begin{array}{l}\text { Distinct, tuberculate, long } \\
\text { paraphysis (Fig. 15- } \longrightarrow \text { ) } \\
\text { or eliophore like structure } \\
\text { more often with coated } \\
\text { dermal appearance or with } \\
\text { the appearance of semi- } \\
\text { coralloid structure } \\
\text { (Fig. } 15-\leftrightharpoons \text { ) }\end{array}$ \\
\hline 3.3 & $\begin{array}{l}\text { Nature of bounded } \\
\text { area }\end{array}$ & $\begin{array}{l}\text { Variable number of cells } \\
(2-5) \text {; each cell } \\
\text { comparatively larger, } \\
\text { penta-, hexa-, polygonal or } \\
\text { rounded in outline } \\
\text { (Fig. 5- }- \text { ) }\end{array}$ & $\begin{array}{l}9 \text { to many cells; cells } \\
\text { comparatively medium in } \\
\text { size, polygonal to rounded } \\
\text { in outline. Less often penta- } \\
\text { to hexagonal (Fig. } 9-\text { - })\end{array}$ & $\begin{array}{l}\text { More than } 20 \text { cells; } \\
\text { comparatively smaller; } \\
\text { cells penta- to hexagonal } \\
\text { in outline (Fig. 13- }- \text { ( ) }\end{array}$ \\
\hline 3.4 & Lumen floor & $\begin{array}{l}\text { Depressed or shallow } \\
\text { glabrous (Fig. 6- } \rightarrow \text { ) }\end{array}$ & $\begin{array}{l}\text { Acutely angled, often } \\
\text { pyramidal terminated into } \\
\text { acute tips, surface glabrous } \\
\text { (Fig. } 10-\square \text { ) }\end{array}$ & $\begin{array}{l}\text { Obtusely rounded, rarely } \\
\text { with obconical outline } \\
\text { (Fig. } 14-\longrightarrow \text { ) }\end{array}$ \\
\hline
\end{tabular}

N. damascena-Sutton (Fig. 2, $\Longrightarrow$ ), provided ornamentation; however, finely dissected involucre of bracts were present in flowers and fruits of both $N$. damascena-Sutton and $N$. damascena-Kew plants. As compared to $N$. sativa, vegetative phase has been prolonged in $N$. damascena plant types and the duration of flowering phase and flowering time ( $N$. sativa-late January to 3rd week of March, harvest-end of March; $N$. damascena-Sutton-1st week of April to 1st week of May, harvest-mid of May; $N$. damascena-Kew-2nd week of March to 1st week of May, harvest-mid of May) have been noted to vary among themselves (Table 1).

Seed surface analysis following SEM: Seeds of $N$. damascena-Sutton were broader, while, seeds of $N$. damascena-Kew were smaller in sizes (Table 2). SEM study of seed surfaces (Figs. 4-15) revealed distinct variations and similarities among the plant types in relation to seed shape, reticulation marks, cells of reticulation, bounded area and lumen floor (Table 2). Marked variations have also been noted between seed surfaces of $N$. damascena-Sutton and $N$. damascena-Kew.

\section{Cytological studies}

Mitotic chromosome analysis performed in the plant types revealed $2 n=12$ chromosomes (Figs. 16-18) in agreement to previous reports (Gregory 1941, Bhattyacharya 1958, Kumar and 


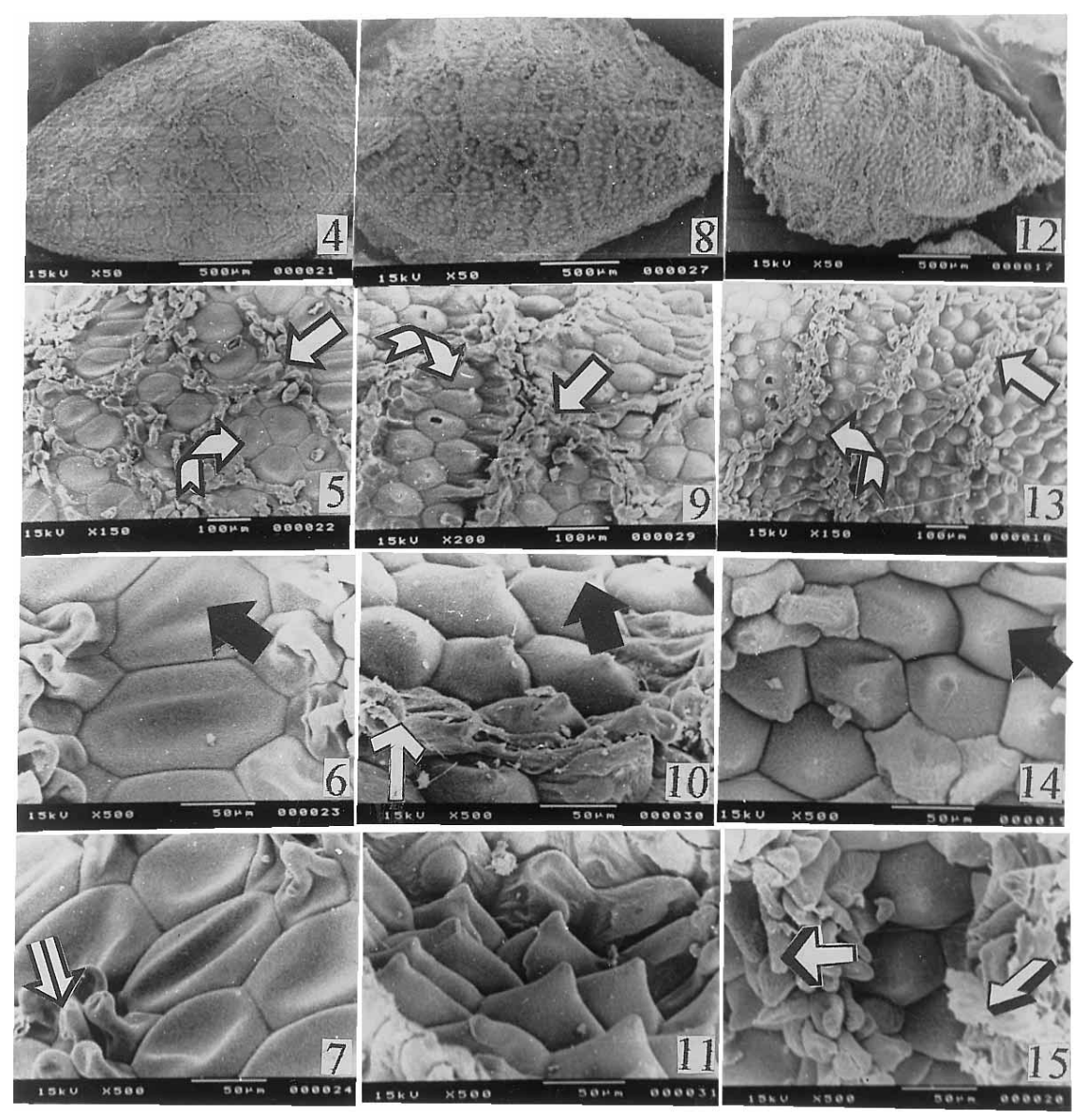

Figs. 4-15. Scanning Electron Microscopy of seed surfaces. 4-7) N. sativa. 8-11) N. damascena-Sutton. 12-15) N. damascena-Kew.

Nizam 1976, Datta and Biswas 1983, Saha and Datta 2002c) and the chromosomes were of 4 types in all cases (Table 3) based on chromosome length, nature of primary constriction and presence or absence of secondary constrictions. The chromosomes in 3 plant types formed graded karyotypes and the karyotypes were symmetric in nature (TF\%-41.38 to 44.18). The somatic chromosomes complements of $N$. damascena (Sutton and Kew samples) possessed 2 pairs of chromosomes with secondary constrictions; while, $N$. sativa had secondary constrictions in 1 pair of chromosomes. Haploid chromatin length has been noted to be highest in $N$. damascena-Kew among the plant types (Table 3).

The chromosomes at metaphase I (Table 3$)$ mostly formed bivalents (5.79 to 5.95) and rarely univalents $(0.10$ to 0.40$)$ per cell. Rod bivalent $(0.20<p<0.30)$ demonstrated random distribution, while ring bivalent per cell $(p<0.01)$ and chiasma per nucleus $(p<0.02)$ were non-random among the plant types as evidenced from $\chi^{2}$ test of heterogeneity. About $22.98 \%$ of the AI meiocytes of $N$. damascena-Sutton (Table 3) demonstrated chromosomal aberrations in the form of dicentric chromatid bridge with an accompanying fragment, laggards (1-4), tripolar organisation of chromosomes and unequal separation of chromosomes; while, in other 2 plant types occasional laggards (1-2) were only observed. Average pollen fertility was high in the plant types (81.61-98.06\%). 

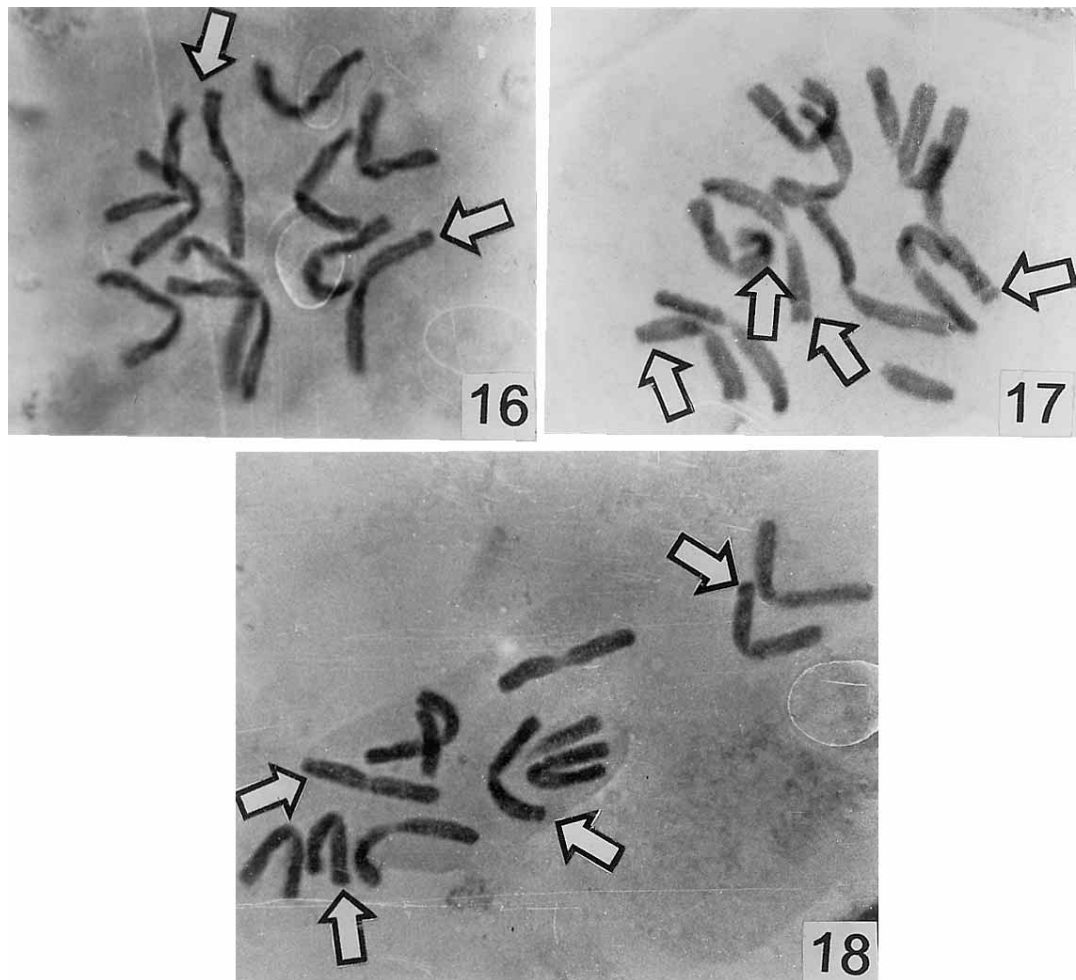

Figs. 16-18. Somatic cells of $N$. sativa (16), N. damascena-Sutton (17) and $N$. damascena-Kew (18) showing $2 n=12$ chromosomes. Chromosomes with secondary constrictions $(\square)$ have been marked.

Table 3. Chromosomal attributes in N. sativa and N. damascena plant types

\begin{tabular}{llll}
\hline \multicolumn{1}{c}{ Attributes } & \multicolumn{1}{c}{ N. sativa } & N. damascena $($ Sutton) & N. damascena (Kew) \\
\hline Mitotic parameters: & & & \\
Chromosome no. & 12 & 12 & 12 \\
Chromosome types & $2 \mathrm{~A}+2 \mathrm{~B}+6 \mathrm{C}+2 \mathrm{D}$ & $2 \mathrm{~A}+4 \mathrm{~B}+4 \mathrm{C}+2 \mathrm{D}$ & $2 \mathrm{~A}+4 \mathrm{~B}+4 \mathrm{C}+2 \mathrm{D}$ \\
Range of chromosome length $(\mu \mathrm{m})$ & $6.64-19.13$ & $5.29-17.66$ & $6.0-18.59$ \\
No. of chromosomes with sec. const. & 2 & 4 & 4 \\
Haploid chromatin length $(\mu \mathrm{m})$ & $85.6 \pm 3.3$ & $71.5 \pm 1.7$ & $94.6 \pm 3.1$ \\
TF\% & 41.38 & 44.18 & 42.32 \\
S\% & 34.71 & 29.95 & 32.30 \\
Karyotype formula & $2 \mathrm{~A}_{\mathrm{m}}+2 \mathrm{~B}_{\mathrm{m}}^{\mathrm{sc}}+6 \mathrm{C}_{\mathrm{m}}+2 \mathrm{D}_{\mathrm{t}}$ & $2 \mathrm{~A}_{\mathrm{m}}+4 \mathrm{~B}_{\mathrm{m}}^{\mathrm{sc}}+4 \mathrm{C}_{\mathrm{m}}+2 \mathrm{D}_{\mathrm{t}}$ & $2 \mathrm{~A}_{\mathrm{m}}+4 \mathrm{~B}_{\mathrm{m}}^{\mathrm{sc}}+4 \mathrm{C}_{\mathrm{m}}+2 \mathrm{D}_{\mathrm{t}}$ \\
Meiotic parameters: & & & \\
Chromosome association/cell at MI & $5.95 \mathrm{II}+0.10 \mathrm{I}$ & $5.79 \mathrm{II}+0.40 \mathrm{I}$ & $5.83 \mathrm{II}+0.33 \mathrm{I}$ \\
Ring bivalent/cell & $3.18 \pm 0.35$ & $2.98 \pm 0.26$ & $2.75 \pm 0.20$ \\
Rod bivalent/cell & $2.77 \pm 0.28$ & $2.86 \pm 0.27$ & $3.07 \pm 0.22$ \\
Chiasma/nucleus & $9.34 \pm 0.28$ & $8.94 \pm 0.22$ & $8.35 \pm 0.25$ \\
PMC scored at MI & 175 & 150 & 148 \\
Equal 6/6 AI sep. $(\%)$ & 94.49 & 77.02 & 98.37 \\
Total cell analyzed at MI & 394 & 148 & 184 \\
Pollen fertility (\%) & 98.06 & 88.01 & 81.61 \\
No. of pollen grains studied & 1174 & 344 & 1383 \\
\hline
\end{tabular}

$\mathrm{m}=$ median, $\mathrm{sc}=$ secondary constriction, $\mathrm{t}=$ telocentric. 


\section{Seed protein characterization}

Seed protein content (Table 1) was maximum in $N$. damascena-Kew ( $22.684 \mathrm{mg} / \mathrm{g}$ of tissue) and minimum in N. sativa (14.346 mg/g of tissue). SDS-PAGE showed differences in the number of bands (Fig. 19), although band width and intensity was similar among the plant types (Table 4). $N$. damascena-Kew exhibited 16 bands while, $N$. damascena-Sutton and N. sativa demonstrated 12 bands. Bands ' 2 ' and ' 6 ' have been found to be specific in $N$. damascena-Kew, while, band ' 4 ', ' 12 ' and ' 16 ' were common in $N$. damascena plant types. Band ' 7 ' and ' 17 ' have been noted in both $N$. sativa and $N$. damascena-Kew but band no. ' 3 ' was only observed in $N$. sativa. Results suggested that electrophoretic characterization of seed protein may be used as an additional parameter to supplement morphological and cytological data in understanding genetic interrelationship among the plant types.

Present study demonstrated gross similarities and differences among/and between the plant types. $N$. damascena-Kew possessed some unique traits specific to themselves apart from $N$. damascena characteristics; however, few traits were found to be similar to $N$. sativa. Results also indicated that $N$. damascena-Sutton plants offered lesser scope of their utilization as germplasm source for species hybridization with $N$. sativa. On the contrary, $N$. damascena-Kew plants having an ornamental phenotype and yielding high number of seeds per plant with good viability and the seeds possessing good amount of protein and essen-

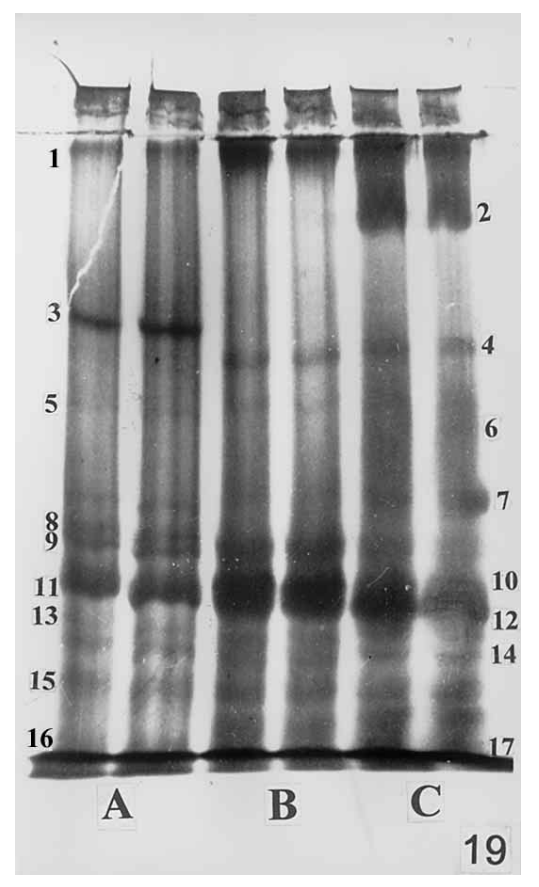

Fig. 19. SDS-PAGE electrophoretic pattern of seed protein from N. sativa (A), N. damascena-Sutton (B) and N. damascena-Kew (C).

Table 4. SDS-PAGE banding pattern of seed protein in three plant types

\begin{tabular}{|c|c|c|c|c|c|c|}
\hline Band No. & $\mathrm{R}_{\mathrm{m}}$ value & N. sativa & N. damascena (Sutton) & N. damascena (Kew) & Band intensity & Band width \\
\hline 1 & 0.03 & + & + & + & I & IM \\
\hline 2 & 0.11 & - & - & + & I & $\mathrm{B}$ \\
\hline 3 & 0.29 & + & - & - & I & IM \\
\hline 4 & 0.35 & - & + & + & I & IM \\
\hline 5 & 0.43 & + & + & + & $\mathrm{F}$ & $\mathrm{N}$ \\
\hline 6 & 0.47 & - & - & + & $\mathrm{F}$ & $\mathrm{N}$ \\
\hline 7 & 0.53 & + & - & + & I & $\mathrm{N}$ to $\mathrm{B}$ \\
\hline 8 & 0.59 & + & + & + & I & $\mathrm{N}$ \\
\hline 9 & 0.65 & + & + & + & I & $\mathrm{N}$ \\
\hline 10 & 0.67 & + & + & + & I & IM \\
\hline 11 & 0.74 & + & + & + & I & IM \\
\hline 12 & 0.77 & - & + & + & I & IM \\
\hline 13 & 0.81 & + & + & + & I & $\mathrm{N}$ \\
\hline 14 & 0.84 & + & + & + & I & IM \\
\hline 15 & 0.89 & + & + & + & I & IM \\
\hline 16 & 0.95 & - & + & + & I & IM \\
\hline 17 & 0.98 & + & - & + & $\mathrm{F}$ & $\mathrm{N}$ \\
\hline
\end{tabular}


tial oil seems to be better suited in present condition and seeds of such a plant type may serve as important genetic stock for further exploration and exploitation in the field of cytogenetics; however, duration of cropping period has to be synchronized with $N$. sativa to offer possibility of interspecific hybridization.

\section{Acknowledgements}

The authors are grateful to Royal Botanic Garden, Kew, London for their generous supply of N. damascena seed stock and to Late Prof. S. Dana (B.C.K.V.), Dr. G. G. Maity (K.U.) and Dr. S. K. Mukherjee (K.U.) for valuable suggestions. Technical help rendered to us by Mr. Amitava Pal and Miss. Sonali Sengupta is gratefully acknowledged.

\section{References}

Arnon, D. I. 1949. Copper enzyme in isolated chloroplast. Polyphenol oxidase in Beta vulgaris. Plant Physiol. $24: 1-15$.

Bhattacharyaya, N. K. 1958. Cytology of two species of Nigella. Genet. Iber. 10: 179-190.

Chakraborty, H. L. and Chakraborty, D. P. 1964. Species of India. Reprinted from Indian Agriculturist 3: $158-159$.

Datta, A. K. and Biswas, A. K. 1983. Karyotype analysis in four Nigella species. Cell and Chromosome Res. 6: 21-23.

— and - 1985. Induced mutagenesis in Nigella sativa L. Cytologia 50: 545-562.

— and - 1986a. Evaluation of quantitative characteristics in some mutant lines of Nigella sativa. Cytologia 51: 289-299.

- and - 1986b. Cytogenetic studies in two induced leaf mutant lines of Nigella sativa. Cytologia 51: 409-417.

— and Rang, S. 2001. A viable chlorophyll mutant in black cumin (Nigella sativa L.). Ind. J. Genet. 61: 293-294.

— and Saha, A. 2001. Male sterility in black cumin (Nigella sativa L.). Plant Archives 1: 45-49.

Gregory, W. C. 1941. Trans. Amer. Phil. Soc. 31: 443 (Cited In: Darlington, C. D. and Wylie, A. D. (eds.). 1955. Chromosome Atlas of Flowering Plants. George Allen and Unwin Ltd., London).

Kumar, P. and Nizam, J. 1976. Induced somatic pairing in Nigella sativa L. Curr. Sci. 45: 32-33.

Laemmli, U. K. 1970. Cleavage of structural proteins during the assembly of the head of bacteriophage $\mathrm{T}_{4}$. Nature 227: 680-685.

Lowry, O. H., Rosebrough, N. J., Farr, A. L. and Randall, R. J. 1951. Protein measurement with Folin-Phenol reagent. J. Biol. Chem. 193: 265-275.

Pruthi, J. S. 1998. Spices and Condiments. National Bool Trust, India. pp. 118-120.

Rang, S. and Datta, A. K. 2001. Mutation in seed coat colour in black cumin (Nigella sativa L.). Ind. J. Genet. 61: 80-81.

Saha, A. and Datta, A. K. 2002a. Induced autotetraploidy in black cumin (Nigella sativa L.). Ind. J. Genet. 62: 275-276.

— and - 2002b. Synaptic mutant with phenotypic marker trait in black cumin (Nigella sativa L.). Plant Archives (in press).

— and - 2002c. Gamma-rays induced reciprocal translocation in black cumin. Cytologia 67: 389-396.

Sengupta, K. 2001. Studies on the cytogenetical aspects of induced mutation and autotetraploidy of coriander (Coriandrum sativum L.). Ph. D. Thesis, Kalyani University.

Worthen, D. R., Ghosheh, O. A. and Crooks, P. A. 1998. The in vitro anti-tumor activity of some crude and purified components of black seed, Nigella sativa L. Anticancer Research 18: 1527-1532. 